\title{
Seismo-acoustic evidence for vent drying during shallow submarine eruptions at Bogoslof volcano, Alaska
}

\author{
David Fee ${ }^{1}$ (1) . John Lyons ${ }^{2} \cdot$ Matthew Haney ${ }^{2} \cdot$ Aaron Wech $^{2} \cdot$ Christopher Waythomas $^{2} \cdot$ Angela K. Diefenbach $^{3}$. \\ Taryn Lopez ${ }^{1} \cdot$ Alexa Van Eaton $^{3} \cdot$ David Schneider $^{2}$
}

Received: 3 October 2018 / Accepted: 10 September 2019/ Published online: 13 December 2019

(C) The Author(s) 2019

\begin{abstract}
Characterizing the state of the volcanic vent is key for interpreting observational datasets and accurately assessing volcanic hazards. This is particularly true for remote, complex eruptions such as the 2016-2017 Bogoslof volcano, Alaska eruption sequence. Bogoslof's eruptions in this period were either shallow submarine or subaerial, or some combination of both. Our results demonstrate how low-frequency sound waves (infrasound), integrated with seismic and satellite data, can provide unique insight into shallow vent processes, otherwise not available. We use simple metrics, such as the infrasound frequency index (FI), event duration, and acoustic-seismic amplitude ratio, to look at changes in the elastic energy radiation and infer changes in seawater access to the vent. Satellite imagery before and after selected eruptions is used to ground-truth inferences on vent conditions. High FI and gradual increases in infrasound frequency content at Bogoslof correspond with transitions from submarine to subaerial vent conditions and a diminished or absent role of water, likely resulting in a drying out of the vent region. Event durations generally correlate with high FI and the range of FI values for each event, suggesting long duration events were more effective at drying out the vent region. A trend from low to high acoustic-seismic amplitude ratios for some long duration events also suggests an increase in acoustic efficiency as the vent dried out. We demonstrate that infrasound can serve as a robust indicator of seawater involvement for Bogoslof and other shallow submarine eruptions that may not be inferable from other datasets, particularly in near-real-time.
\end{abstract}

Keywords Seismo-acoustic $\cdot$ Infrasound $\cdot$ Bogoslof volcano $\cdot$ Submarine

\section{Introduction}

Volcanic eruptions are dynamic and complex, and multiple types of observations are typically necessary to unravel physical processes and formulate source models that facil-

Editorial responsibility: K. Wallace

This paper constitutes part of a topical collection:

The 2016-17 shallow submarine eruption of Bogoslof volcano, Alaska

$\triangle$ David Fee

dfee1@alaska.edu

1 Alaska Volcano Observatory, Geophysical Institute, University of Alaska Fairbanks, Fairbanks, AK, USA

2 Alaska Volcano Observatory, U.S. Geological Survey, Anchorage, AK, USA

3 Cascades Volcano Observatory, U.S. Geological Survey, Vancouver, WA, USA itate effective monitoring and interpretation of eruption dynamics. Combining seismic and acoustic data with other observations can provide valuable insights, for example, characterizing subsurface vs. subaerial processes and the partitioning of elastic energy (Fee and Matoza 2013; Johnson and Aster 2005). Analyzing images of post-eruption topographic changes can help confirm eruption processes inferred from the seismo-acoustic data, and can assist in constructing source models (Fee et al. 2017, Johnson et al. 2018). Careful evaluation of changes in the frequency content of seismo-acoustic data also provides information on event type (e.g., long period vs. volcano-tectonic earthquake) and source depth, which can be useful in eruption forecasting (Buurman and West 2006, Johnson et al. 2018).

Bogoslof volcano, Alaska (Fig. 1) began erupting in late December 2016 with little warning, producing 70 explosive eruptive events before ceasing in late August 2017. Bogoslof is a low-profile, back-arc volcano in the central Aleutian arc characterized by a largely submarine edifice. The vent was likely submerged for the majority of the 
Fig. 1 Map of Bogoslof and surrounding region, including regional seismic (MAPS, gray square) and infrasound stations (OKIF, black circle) used here

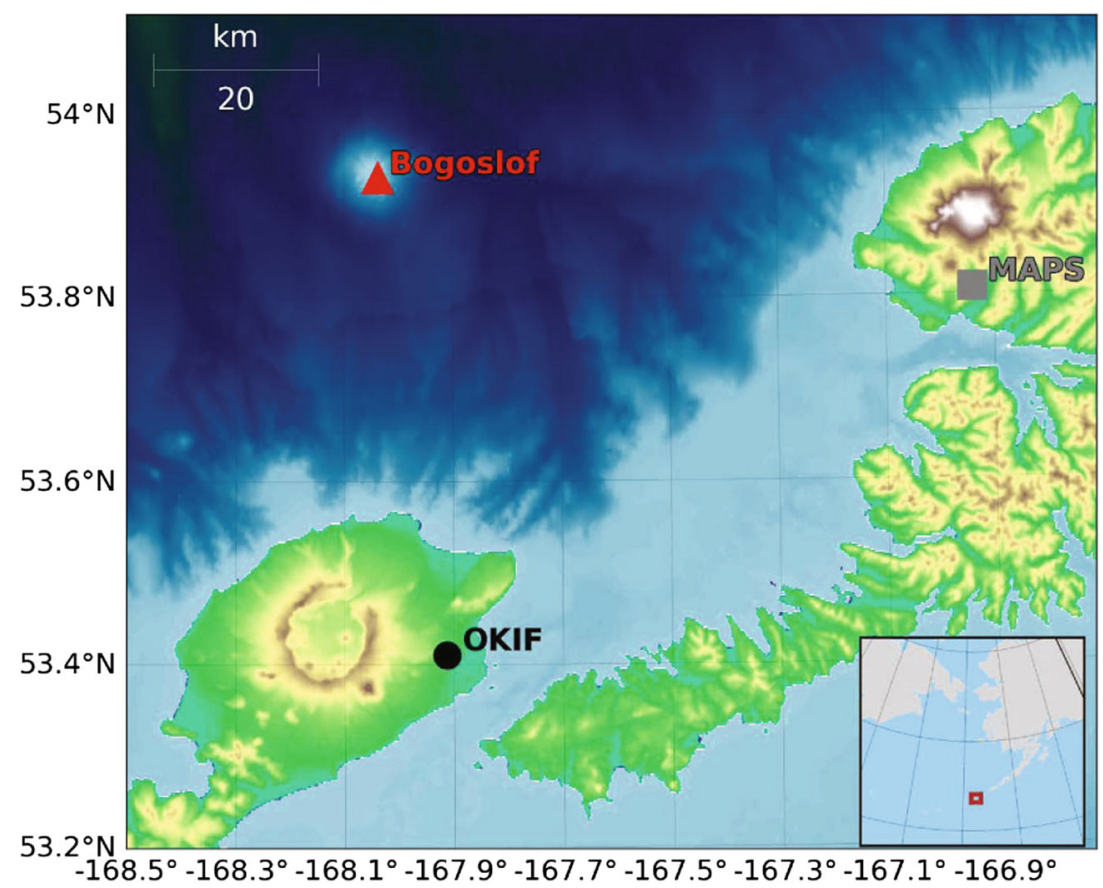

2016-2017 eruptive period, although the vent likely breached the surface in all or most eruptions (Lyons et al. 2019). The Alaska Volcano Observatory (AVO) had no onsite monitoring stations due to the small size of the island, wilderness and wildlife designation, and ongoing hazard; therefore, it relied on regional seismic and acoustic data along with lightning, visual, and satellite observations for monitoring the eruption (Coombs et al. 2018). Based on past Bogoslof eruptions (Waythomas and Cameron 2018) and visual and satellite observations, AVO inferred that many of the eruptions were Surtseyan or Taalian in nature, which involves phreatomagmatic eruptions in a water-flooded vent that is commonly encircled by a tephra ring (Kokelaar 1983). The eruptive mixture during Surtseyan eruptions is often a slurry of magma, hyaloclastite (quenched glass), and sediment-rich water. Vigorous steam- and tephra-laden jets were occasionally visible, driving eruption columns up to aircraft cruising altitudes (6-12 km above sea level) (Schneider et al. 2019). The submerged vent and lack of local observations at Bogoslof created additional complexities for inferring eruption processes and associated hazards.

Atmospheric infrasound from submarine sources is inherently complex. The high impedance contrast at the water-air interface inhibits sound transmission by reflecting sound downward. However, when the sound wavelength is much larger than the source depth a phenomenon known as "anomalous transparency" may occur where much of the sound energy incident upon the water/air interface is transmitted into the atmosphere (Godin 2006, Evers et al. 2014). Infrasound from submarine volcanic sources has not been studied in great detail. Jolly et al. (2010) looked at seismic and acoustic data from the 2007 Ruapehu, New Zealand eruption that occurred within the volcanic crater lake and found that seismic tremor was coincident with a very long period acoustic pulse, suggesting a short-duration explosion through the crater lake. Green et al. (2013) analyzed seismic, hydroacoustic, and infrasound data from the 2010 South Sarigan submarine eruption and found powerful infrasound recorded over $1500 \mathrm{~km}$ away. Although the vent was likely several hundred meters below sea level, Green et al. (2013) suggest that the infrasound originated from a subaerial eruption column. The lack of detailed observations and local data did not allow for additional source constraints. The majority of Bogoslof eruptions likely began with a submarine vent, although most or all likely breached the surface. To our knowledge, infrasound associated with shallow submarine eruptions where the initial water depth over the vent is on the order of tens of meters (e.g., Surtseyan) has not been reported prior to this eruption. Haney et al. (2018, 2019) discuss infrasound from volcanic thunder produced during the recent Bogoslof eruption, a process originating from within the volcanic plume and not the vent (Van Eaton et al. 2019).

Changes in the water level above the vent at Bogoslof (and other volcanoes) will affect eruption processes and the associated geophysical, geological, and geochemical observations (e.g., Belousov and Belousova (2009), Jolly et al. (2010), and Kilgour et al. (2010)). For infrasound waves traveling through deep water, the anomalous transparency phenomenon effectively acts as a low-pass acoustic filter, which only allows low frequencies with wavelengths much larger than the source depth to propagate efficiently into the 
atmosphere. During shallow water Surtseyan eruptions, similar to what we assume for much of the Bogoslof activity, water is incorporated into the eruptive mixture and flashed to steam, and the lateral forces associated with the rapidly ascending eruption column will displace water, effectively diminishing or inhibiting direct water interaction with the erupting vent (Kokelaar 1983). Compared to a deep submarine vent, elastic wave energy emanating from a "dry" or subaerial vent will more efficiently radiate into the atmosphere, increasing the proportion of acoustic to seismic energy, and will also permit more broadband acoustic radiation. Large, crater-sized bubbles with a liquid film may also develop during shallow submarine explosions (Belousov and Belousova 2009, Morimoto and Ossaka 1955), such as those observed during the 1908 Bogoslof eruption (Prosser 1911). Lyons et al. (2019) analyze low-frequency infrasound explosions from Bogoslof and propose a source model of very large bubbles oscillating and then bursting. Sufficient water in the eruption mixture could potentially enhance scrubbing of $\mathrm{SO}_{2}$ (Symonds et al. 2001) and early fallout of volcanic ash as accretionary lapilli (Van Eaton et al. 2015). Preliminary satellite-based observations indicate the 2016-2017 Bogoslof eruption was relatively $\mathrm{SO}_{2}$ and water-rich for most events (Lopez et al. 2019; Schneider et al. 2019). Therefore, information on the location of the vent with respect to sea level and related shallow water eruption processes is key to understanding the eruption and associated geophysical observations.

In this manuscript, we combine seismic and acoustic data to infer shallow water eruption processes at Bogoslof volcano. We use simple metrics based on the infrasound frequency content, infrasound event duration, and ratio of acoustic-seismic amplitude to infer the state of the vent region, particularly whether it was dry and open to the atmosphere or submerged by seawater. High-resolution visiblewavelength satellite observations and associated digital elevation models (DEMs) of the subaerial configuration of the island provide evidence of vent depth, water displacement, and related vent drying.

\section{Data and methods}

We use regional seismo-acoustic data from AVO networks (Fig. 1). Infrasound array OKIF was a 4-element array located $\sim 60 \mathrm{~km}$ south of Bogoslof on Umnak Island (Fig. 1). The array consisted of Chaparral Physics Model 25Vx sensors sampled at $100 \mathrm{~Hz}$ by a Quanterra Q330 digitizer. The array aperture was $\sim 100 \mathrm{~m}$ and each element had wind noise reduction. The sensor-digitizer flat passband is $\sim 0.1-50 \mathrm{~Hz}$. Array data are processed to determine coherent acoustic signals using a least squares algorithm (e.g., Szuberla and Olson (2004)). Infrasound data are considered to have originated from the volcano if the data segment had an acoustic trace velocity $(0.25-0.45 \mathrm{~km} / \mathrm{s})$, back-azimuth within $\pm 15^{\circ}$ of the actual, and a median cross-correlation maximum (MdCCM) above 0.5. MdCCM is determined by finding the median of the maximum crosscorrelation between unique array element pairs (Lee et al. 2013 ) in 30 s of segments with $50 \%$ overlap. Acoustic travel time is removed assuming a constant propagation velocity of $0.34 \mathrm{~km} / \mathrm{s}$. See Haney et al. (2018) and Schwaiger et al. (2019) for more details on acoustic propagation between Bogoslof and the OKIF array. Data are filtered between $0.1-10 \mathrm{~Hz}$ for array processing. This relatively broad frequency band is chosen to capture the wide range of frequencies produced by Bogoslof and to be consistent with the frequency index calculations (see below). We determine infrasound event durations by summing the coherent data segments originating from Bogoslof. Delay-and-sum beamforming for a source originating from Bogoslof is applied to increase the signal-noise ratio. Other infrasound arrays in the region recorded Bogoslof eruptions, but are generally at much greater distances with increased path effects. OKIF provides the most complete acoustic dataset and recorded 41 out of the total 70 explosive events identified by AVO. AVO's event identification involved detailed multiparameter analysis of the eruption sequence (Coombs et al. 2019)

We analyze seismic data from station MAPS located $\sim 73 \mathrm{~km}$ east of Bogoslof on Makushin volcano, Unalaska Island (Fig. 1). This station consists of a 3-component Guralp CMG-6TD seismometer with a built-in digitizer. Although other seismic stations are closer to Bogoslof, MAPS is broadband, digital, and ran nearly continuously during the eruption sequence. The sensor response is flat between $30 \mathrm{~s}$ and $100 \mathrm{~Hz}$, and the response has been removed. We only analyze the vertical channel. Seismic travel time is accounted for assuming a $5-\mathrm{km} / \mathrm{s}$ velocity. All times listed are in UTC and plume heights are above sea level.

The frequency index (FI) (Buurman and West 2006) is used to examine changes in infrasound frequency content. FI is calculated using the following:

$\mathrm{FI}=\log _{10} \frac{A_{\text {upper }}}{A_{\text {lower }}}$

where $A_{\text {upper }}$ are the mean spectral estimates from an upper frequency band and $A_{\text {lower }}$ are the mean spectral estimates from a lower frequency band. Here, we define $A_{\text {lower }}$ between 0.1 and $1.0 \mathrm{~Hz}$ and $A_{\text {upper }}$ between 1 and $10 \mathrm{~Hz}$. Similar to infrasound array processing, spectra are computed in $30 \mathrm{~s}$ segments with $50 \%$ overlap. FI is calculated only for the infrasound data when the aforementioned array processing thresholds are met. Elevated low-frequency 
noise and the microbarom could influence the array detections and FI calculation, although this should be relatively minor due to our strict array processing thresholds.

The acoustic to seismic ratio is computed to examine changes in energy partitioning. Johnson and Aster (2005) defined the useful metric volcano acoustic-seismic ratio (VASR) as the ratio between the acoustic and seismic energy emitted from a volcano. The seismic energy calculation includes terms on density, attenuation, and site response that are likely complicated and poorly constrained for this eruption. Similarly, the acoustic energy calculation also relies on propagation and isotropic source radiation assumptions, which are also poorly constrained here. Because of this, we choose to simply analyze the ratio of the seismic and acoustic amplitude envelopes and refer to this modified metric as VASR*. We filter the acoustic waveforms between 0.1 and $10 \mathrm{~Hz}$ and the seismic data from 1.0 to $10 \mathrm{~Hz}$ with acausal butterworth filters. The higher seismic corner frequency is chosen to minimize contamination from the microseism. These filter bands capture the majority of the broadband seismo-acoustic energy from Bogoslof. The analytic signal of the Hilbert transform is then used to obtain the amplitude envelopes. Since we are interested in only gross source changes over long durations, envelopes are then averaged over 15-s intervals and smoothed using a 3-min duration convolutional filter. Similar to the infrasound FI, we examine VASR* only during data segments where infrasound array thresholds are met.

We acknowledge that seasonal propagation variations may affect the infrasound signals (Iezzi et al. 2018;
Schwaiger et al. 2019). Due to the long duration of the 2016-2017 Bogoslof sequence, acoustic propagation likely varied between different periods of the eruption and certain events may have had more favorable propagation than others. Schwaiger et al. (2019) examine this in more detail. Because of these variations, we suggest VASR* is most useful over time periods of a single eruptive event or several days, but is difficult to compare over the entire sequence. Therefore, we only examine VASR* over the course of individual events. Infrasound frequency content should be less susceptible to changing propagation conditions than the amplitude.

Satellite observations used here are taken from available cloud-free images before and after selected eruptions. We primarily use Worldview-2 and -3 imagery, as well as Landsat 8, COSMO-SkyMed, and Sentinel-2. The DEM was created using the NASA Ames Stereo Pipeline (ASP) software package (Shean et al. 2016) with the January 31, 2017 Worldview-2 imagery. In this manuscript, we restrict our satellite-based analysis to qualitative observations, and focus on the changes in island morphology and how they relate to the seismo-acoustic data. More detailed satellite-based observations and interpretation are available in separate manuscripts, such as Waythomas et al. (2019) and Schneider et al. (2019). Details on satellite-derived $\mathrm{SO}_{2}$ and lightning observations are available in Lopez et al. (2019) and Van Eaton et al. (2019), respectively.

The majority of explosive events that occurred during the 2016-2017 eruption consisted of short-duration, explosionlike seismic, and acoustic signals with low FI. Figure 2

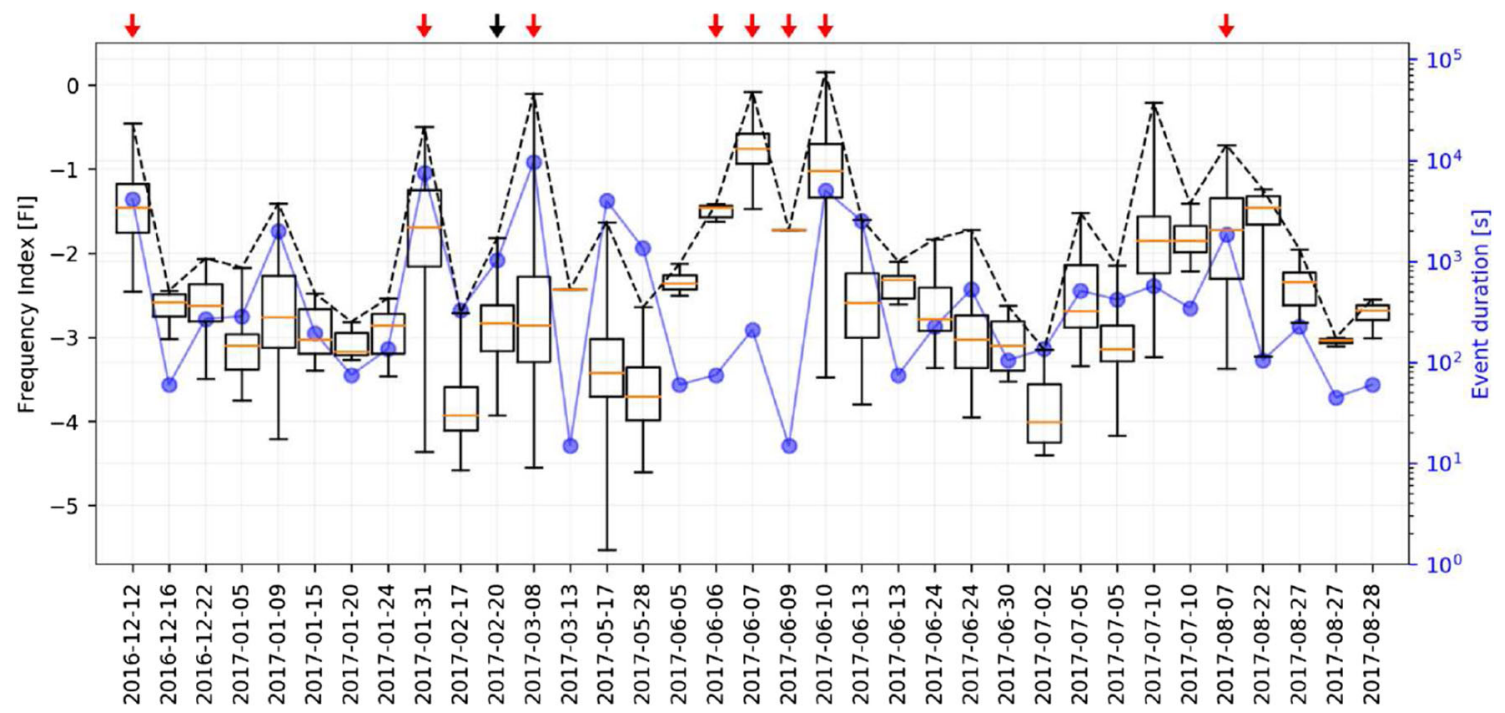

Fig. 2 Infrasound frequency index and event duration for the 20162017 Bogoslof eruption sequence. The box and whisker plot of infrasound FI represents the median (orange line), interquartile ranges (boxes), and full range of values (whiskers) for each event recorded at OKIF. The black-dashed line connects the highest FI for each event.
The blue line denotes event durations and the red arrows indicate eruptions where satellite imagery suggest the vent was subaerial. The black arrow indicates the submarine February 20, 2017 eruption. Subaerial vents generally correspond with high FI and event durations. Note we plot only events with infrasound recorded at station OKIF (Fig. 1) 
displays the FI for the 35 events detected at the OKIF infrasound array during the 2016-2017 Bogoslof eruption sequence. FI values for most events are below -2 , and the mean of all FI observations is -2.3 . Seven events have FI values that exceed -1 : December 12, 2016, January 31, 2017, March 8, 2017, June 7, 2017, June 10, 2017, July 10, 2017, and August 7, 2017 (Table 1). Satellite analysis suggests the vent was subaerial or "dry" during some point of all of these high FI eruptions, except for July 10, 2017 (Fig. 2). Below, we analyze most of these high FI eruptions and compare them to a more typical Bogoslof eruption from February 20, 2017.

Infrasound event durations vary greatly and generally correlate with peak FI values (Fig. 2). Event durations range from $15 \mathrm{~s}$ for a couple of events up to $9690 \mathrm{~s}$ (161.5 min) on March 8, 2017. Eight events have durations longer than 1800 s (30 min): December 12, 2016, January 9, 2017, January 31, 2017, March 8, 2017, May 17, 2017, June 10, 2017, June 13, 2017, and August 7, 2017 (Table 1). These long duration events also have generally high FI values. Comparison of the peak FI and $\log 10$ of the duration for each event gives a linear correlation coefficient of 0.62 .

Comparison of the range of FI values for each event with the event duration shows a strong correlation. Figure 3 plots the range of FI values (maximum FI-minimum FI) vs. the event duration for each eruption. The durations are plotted on a logarithmic scale. The correlation coefficient between the FI range and $\log 10$ of the duration is 0.91 . This shows that longer events have a wider range of frequencies.

Satellite observations of Bogoslof during the 2016-2017 eruptive period generally showed a submerged vent, located within a small bay open to the sea or enclosed by a tephra ring. However, on several occasions, imagery also showed a vent on land (December 12), a lava dome that breached the water surface (early June), or water draining back into a dry crater following an eruption (January 13 and

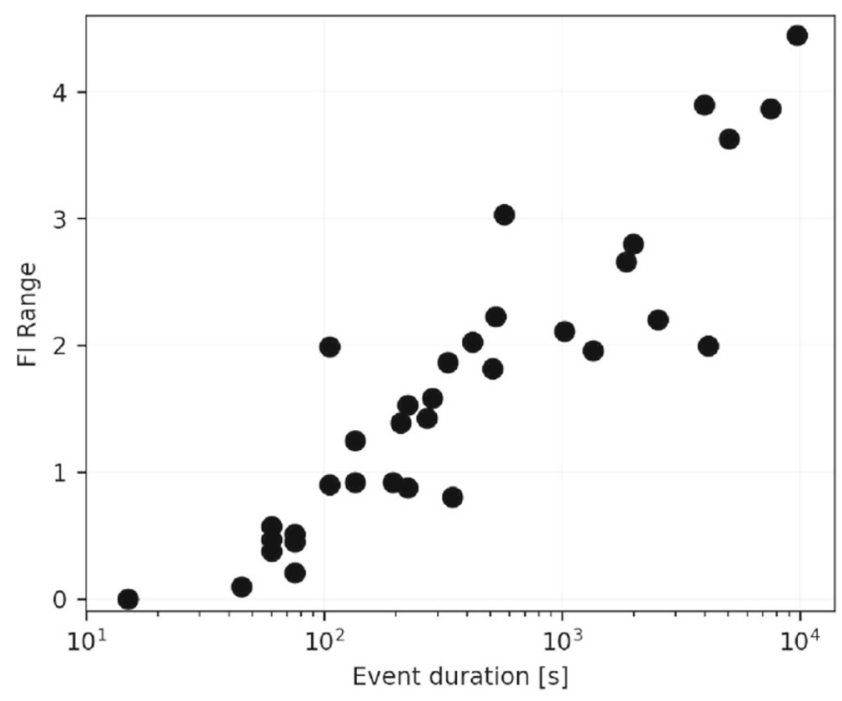

Fig. 3 Comparison of FI range versus the event duration. Durations are plotted on a logarithmic scale

March 8). The red arrows in Fig. 2 represent independent satellite-based evidence of a dry or subaerial eruptive vent and are discussed in detail later. In general, these time periods correspond with events with high FI $(>-1)$ and long durations ( $>1000 \mathrm{~s} / 17 \mathrm{~min}$ ). Below we analyze the seismoacoustic character and FI and VASR* values for selected events and then discuss inferences on vent characteristics. Available satellite images before and after the eruption are used to infer the state of the vent. Table 1 summarizes the observations from the eruptive events this manuscript focuses on.

Figure 4a shows the seismo-acoustic waveforms, spectrograms, FI, and VASR* for the December 12, 2016 eruption (event 2). This event has relatively high FI values, peaking at -0.5 , but the character of the eruption is different from the other high FI events. This eruption consists of numerous

Table 1 Summary of observations for events with FI greater than -1 , as well as the Feb. 20, 2017 eruption more typical of events during the eruption sequence

\begin{tabular}{|c|c|c|c|c|c|c|c|c|}
\hline Eruption date & FI & $\begin{array}{l}\text { Infrasound } \\
\text { amplitude }(\mathrm{Pa})\end{array}$ & $\begin{array}{l}\text { Infrasound } \\
\text { duration }(\mathrm{s})\end{array}$ & $\begin{array}{l}\text { Peak VASR* } \\
(\mathrm{Pa} / \mathrm{um} / \mathrm{s})\end{array}$ & $\begin{array}{l}\text { Plume height } \\
(\mathrm{km})\end{array}$ & $\begin{array}{l}\text { Lightning } \\
\text { (strokes) }\end{array}$ & $\begin{array}{l}\mathrm{SO}_{2} \\
(\mathrm{kt})\end{array}$ & Satellite interpretation \\
\hline 12 Dec. 2016 & -5.7 to -0.5 & 1 & 4200 & 0.0012 & nd & nd & nd & Subaerial_vent \\
\hline 31 Jan. 2017 & -4.4 to -0.5 & 2.1 & 7530 & 0.0032 & 5.9 & 223 & 3.6 & Subaerial vent drying \\
\hline 20 Feb. 2017 & -3.9 to -1.8 & 19 & 225 & 0.0078 & 6.1 & 21 & 0.7 & Shallow submarine \\
\hline 8 Mar. 2017 & -4.5 to -0.1 & 11 & 9690 & 0.0071 & $10.6 / 13.4$ & 1557 & 21.5 & Subaerial vent drying \\
\hline 7 Jun. 2017 & -1.5 to -0.1 & 2.7 & 210 & 0.0020 & 1.5 & nd & nd & Subaerial-dome \\
\hline 10 Jun. 2017 & -3.5 to -0.2 & 0.75 & 5040 & 0.00014 & 9.5 & 36 & 1.6 & Subaerial-dome \\
\hline 10 Jul. 2017 & -3.2 to -0.2 & 3 & 570 & 0.00075 & nd & nd & nd & nd \\
\hline 7 Aug. 2017 & -3.4 to -0.7 & 1.5 & 1860 & 0.0018 & $10.8 / 12.7$ & 121 & 5.8 & Subaerial vent drying \\
\hline
\end{tabular}

"nd" indicates no detection. Plume heights and $\mathrm{SO}_{2}$ masses are derived via satellite data and are detailed in Schneider et al. (2019) and Lopez et al. (2019), respectively. Lightning strokes are those detected by WWLLN and are discussed in Van Eaton et al. (2019) 
short-duration explosions spaced closely together, which is typical of many of the Bogoslof eruptions with lower FI (e.g., February 20, 2017). However, the December 12 explosions have much higher frequency content. Satellite images of Bogoslof on December 14 suggest a small vent near the center of the island (Fig. 4b). The vent may thus have been above ground or submerged in only very shallow water. A December 1 image from before this event showed no vent or open water in the center of the island. Infrasound amplitudes peak at $\sim 1 \mathrm{~Pa}$. VASR $*$ is mostly low for this event but has a couple bursts just above $0.0001 \mathrm{~Pa} / \mu \mathrm{m} / \mathrm{s}$. Seismic background noise is relatively high. No significant plume, $\mathrm{SO}_{2}$, or lightning were detected from this eruption (Table 1). There was a weaker eruption earlier on December 12 apparent only in the infrasound data. It is notable that these two events represent the first infrasound detected from Bogoslof and likely the opening stages of the eruption sequence.
The Bogoslof eruption on January 31, 2017 (event 29) has marked changes in FI and VASR*. Figure 5 shows the seismo-acoustic waveforms, spectrograms, FI, and VASR* for $9 \mathrm{~h}$ surrounding this eruption, plotted in a similar manner to Fig. 4a. The infrasound begins around 05:21 with a number of relatively low-amplitude, short-duration signals (explosions). The frequency content of these events is low, with the FI during this period mostly below -3 . Around 08:30, the infrasound character changes to sustained, more broadband signals with higher amplitudes. FI during this period rises to approximately -1 . After a brief pause, eruption signals begin again around 09:45 and last for $\sim 60 \mathrm{~min}$, with infrasound amplitudes peaking around 10:20 and FI increasing to around -0.5. After a pause in the eruption, two infrasonic pulses occur over the next hour. The seismicity for this eruption primarily consists of transient earthquakes followed by intermittent a)

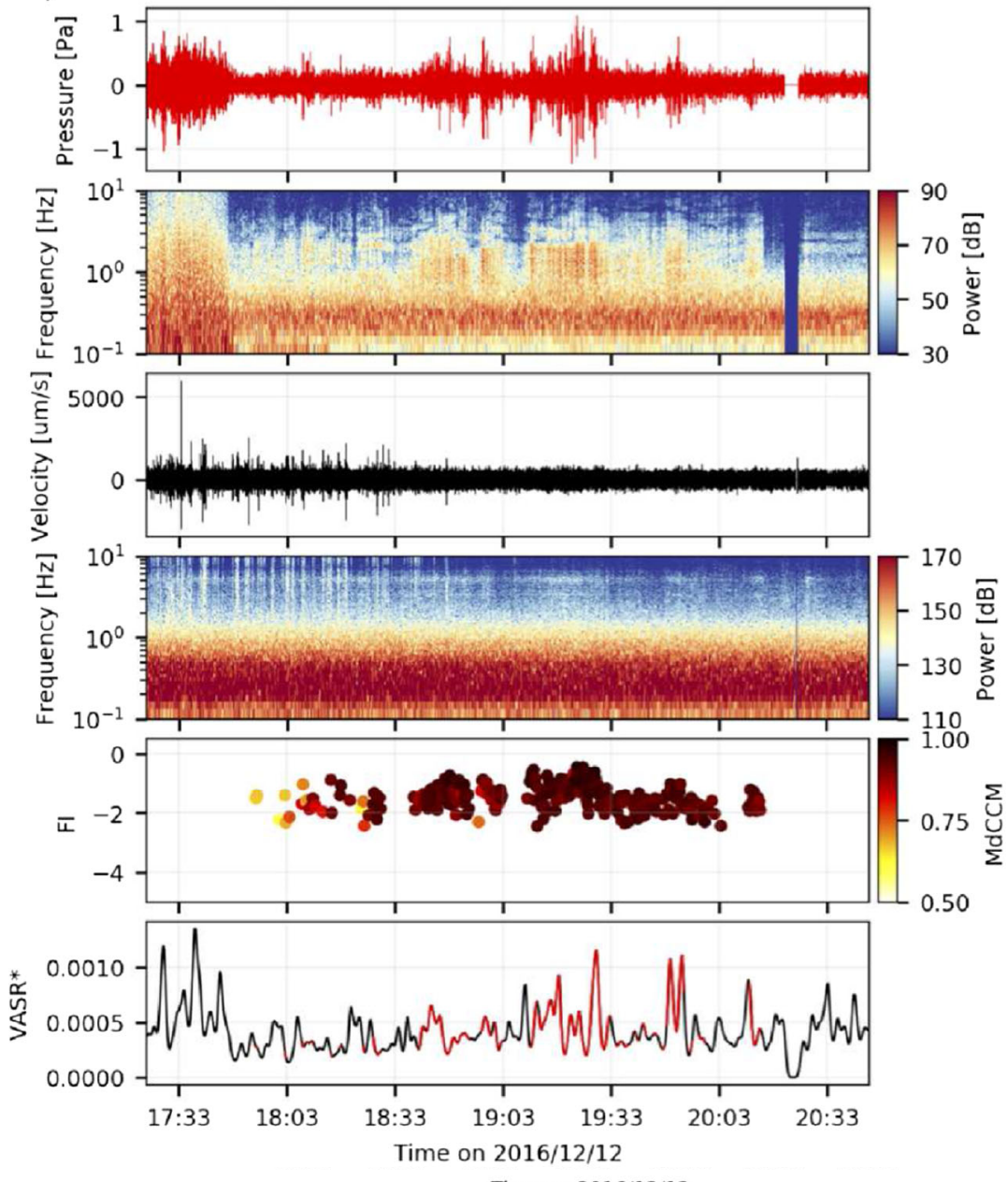

b)

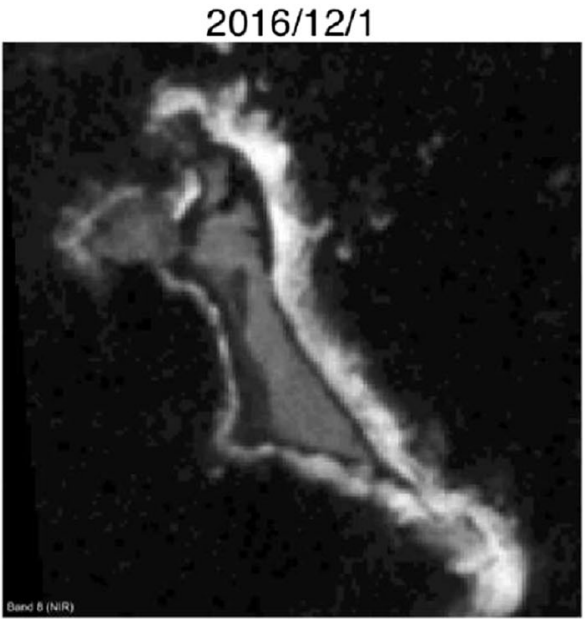

㖇 2016/12/14

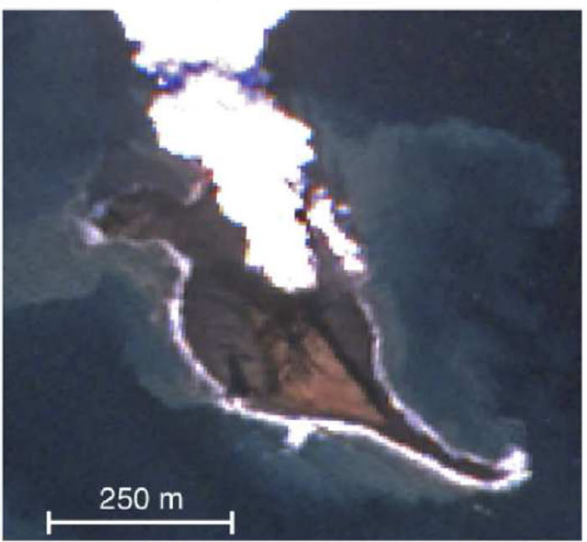

Time on 2016/12/12

Fig. 4 Seismo-acoustic data and metrics for the December 12, 2016 eruption and before and after satellite images. a) The panels are $0.1-10 \mathrm{~Hz}$ filtered infrasound data, infrasound spectrogram, 0.1-10 Hz filtered seismic data, seismic spectrogram, infrasound FI, and VASR*.
FI is plotted and VASR* is red only when infrasound array thresholds are exceeded. b) Sentinel 2 images of Bogoslof on December 1 and 14. Images are oriented with north towards the top and the island was $\sim 1200 \times 500 \mathrm{~m}$ in max length and width 
a)

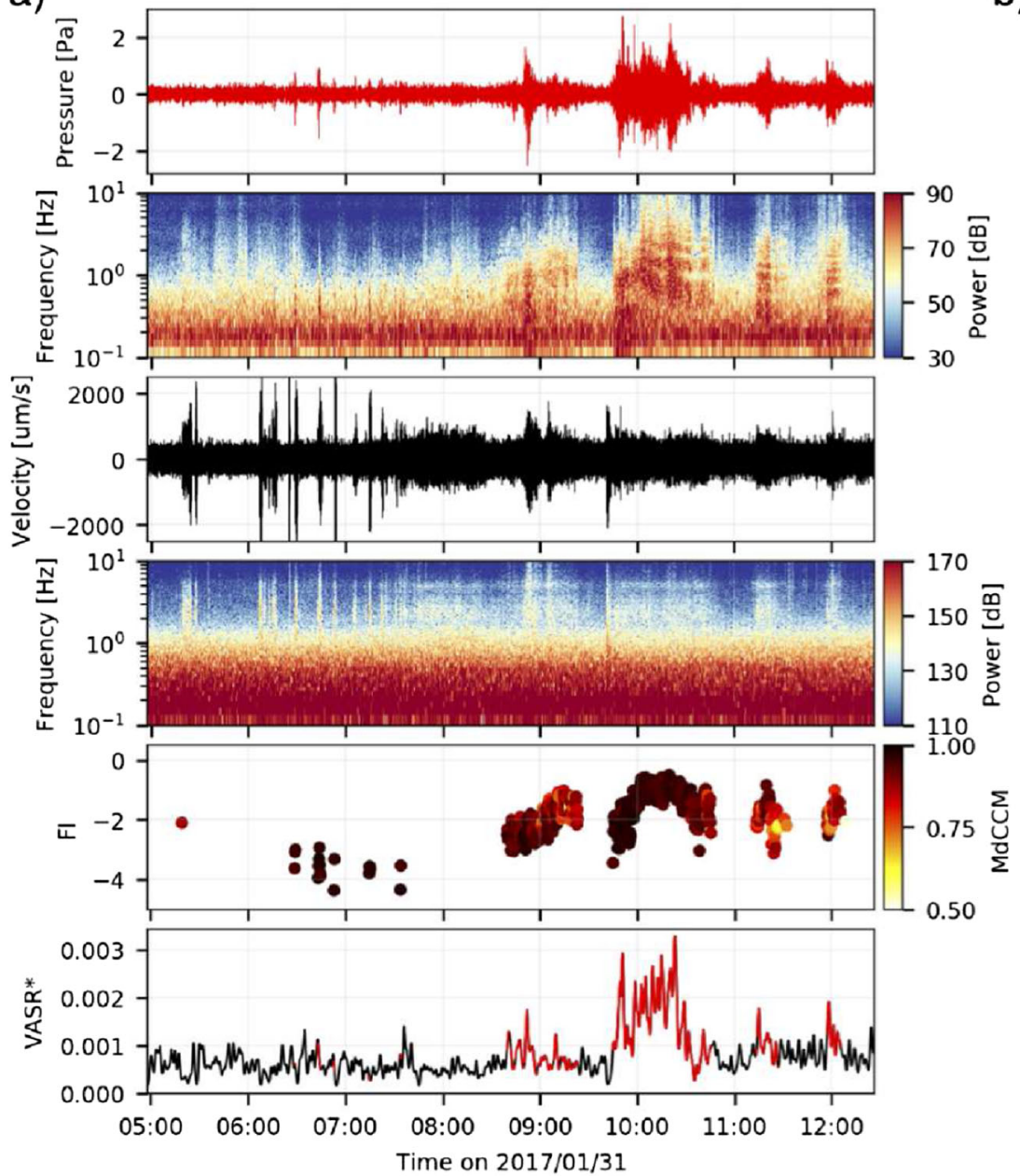

b)

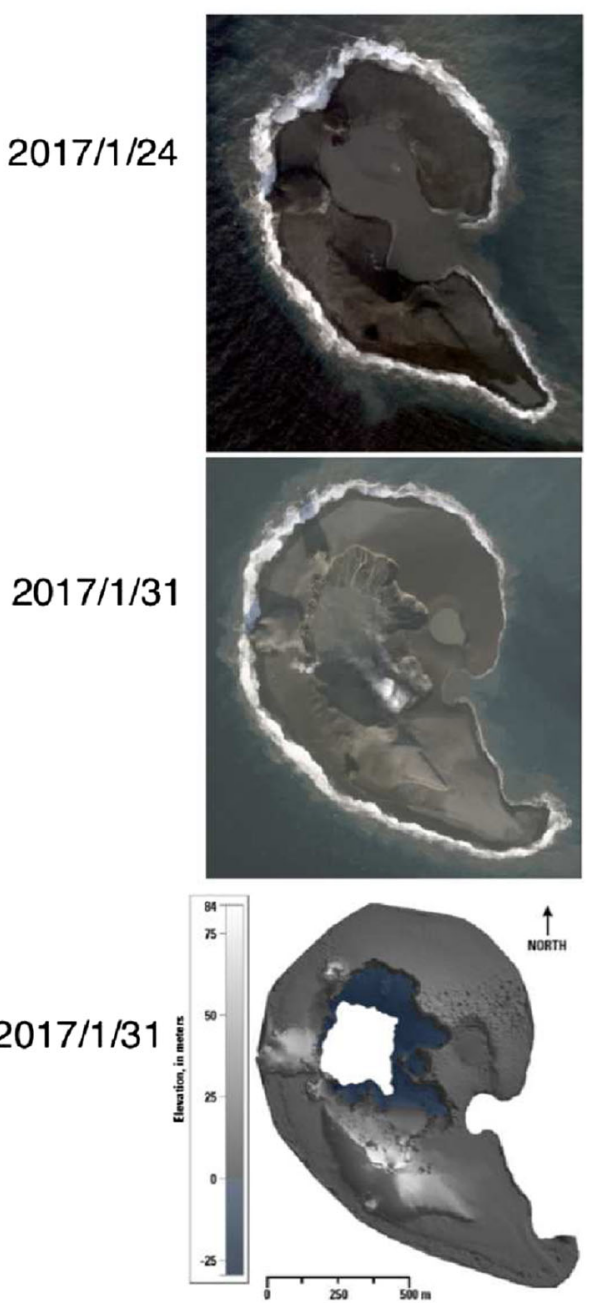

Fig. 5 Seismo-acoustic observations for the January 31, 2017 eruption and before and after satellite images. a) The panels are $0.1-10$ $\mathrm{Hz}$ filtered infrasound data, infrasound spectrogram, 0.1-10 Hz filtered seismic data, seismic spectrogram, infrasound FI, and VASR*,

tremor between $\sim 07: 30$ and 13:30; otherwise, no significant amplitude or frequency changes are apparent and the microseism and other ocean-related noise dominates frequencies below $1 \mathrm{~Hz}$. The VASR* generally follows the infrasound amplitudes as the seismic amplitudes stay roughly constant. High VASR* values typically correspond to time periods with high FI.

Satellite images of the island prior to January 31 suggest the vent region was underwater and located in a small ( $\sim 250$-m wide) bay that likely represented the eruption crater (Fig. 5b). A WorldView-2 satellite image from after the eruption shows the morphology of the island markedly changed during the January 31 eruption (Fig. 5b), as the crater was no longer open to the sea and was below sea level. Water was clearly visible draining back into the vent. A DEM created from this imagery (Fig. 5b) suggests the vent was at least $20 \mathrm{~m}$ below sea level and that the eruption expelled all of the existing water and built a tephra collar similar to Fig. 3. b) WorldView-2 images from January 24 to January 31,2017 , and a DEM created from the January 31 image show marked differences in island morphology and water draining back into the crater on January 31 .

that temporarily restricted seawater interaction at the vent. The topographic barrier separating the crater region from the sea is composed of pyroclastic deposits (Waythomas et al. 2019). The January 31 eruption also represented a change in observed volcanic emissions. Satellite data indicates the first eruption cloud was visible by 05:30 UTC and reached a height of $5.9 \mathrm{~km}$. This eruption had a clear ash signal in the satellite data and produced trace ashfall on Unalaska Island and Dutch Harbor $\sim 100 \mathrm{~km}$ east of the volcano (Schneider et al. 2019). Ash was only detected previously from event 23 on January 18 . Above-average $\mathrm{SO}_{2}$ was also detected (3.6 kt compared to an average of $2 \mathrm{kt}$ ) (Lopez et al. 2019).

Figure 6a displays the seismo-acoustic waveforms, spectrograms, FI, and VASR* for $2.5 \mathrm{~h}$ surrounding a typical eruption during the 2016-2017 eruption sequence, February 20, 2017 (event 36). No infrasound is apparent until a rapid onset around 02:11. Numerous short-duration, 


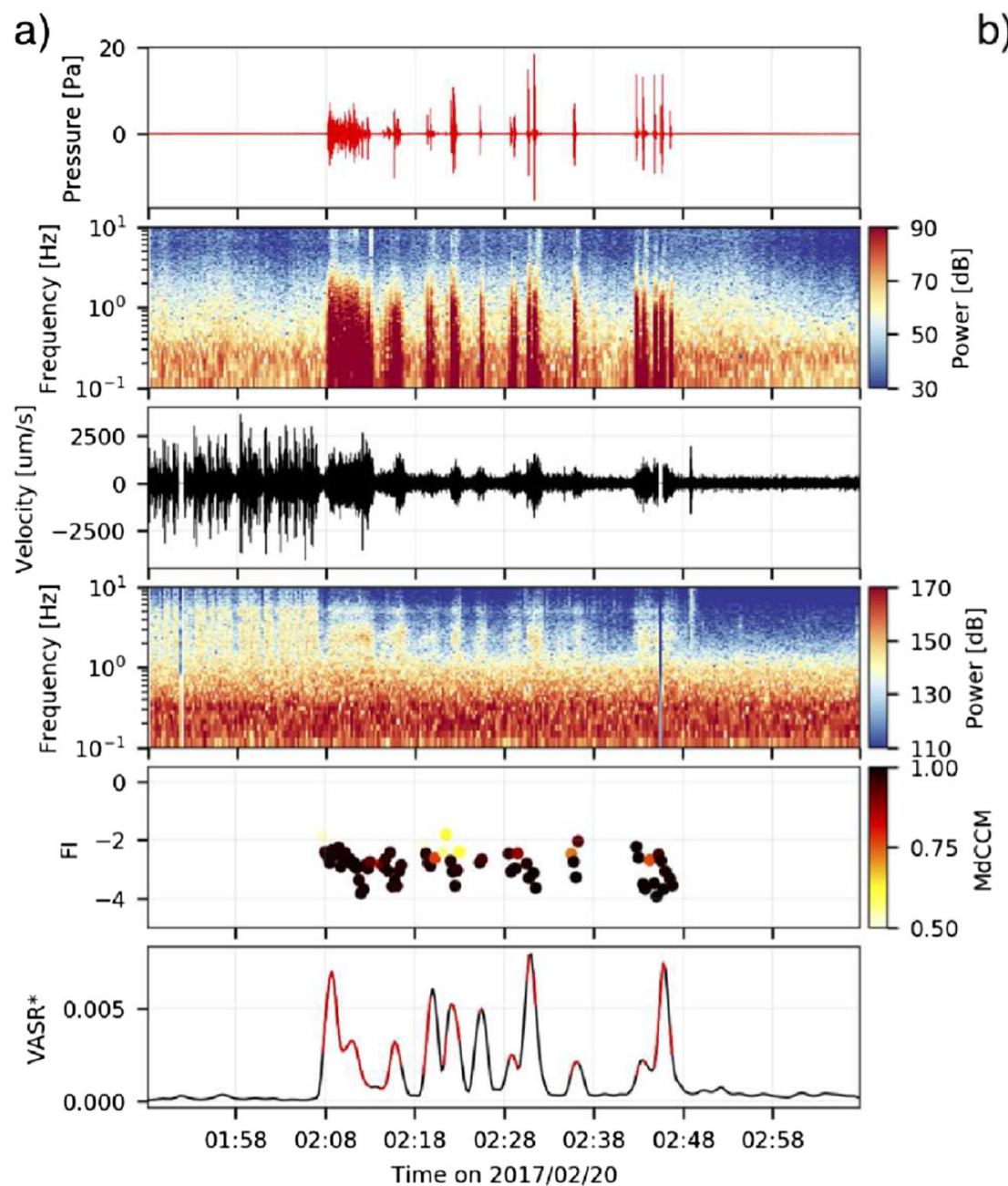

b)
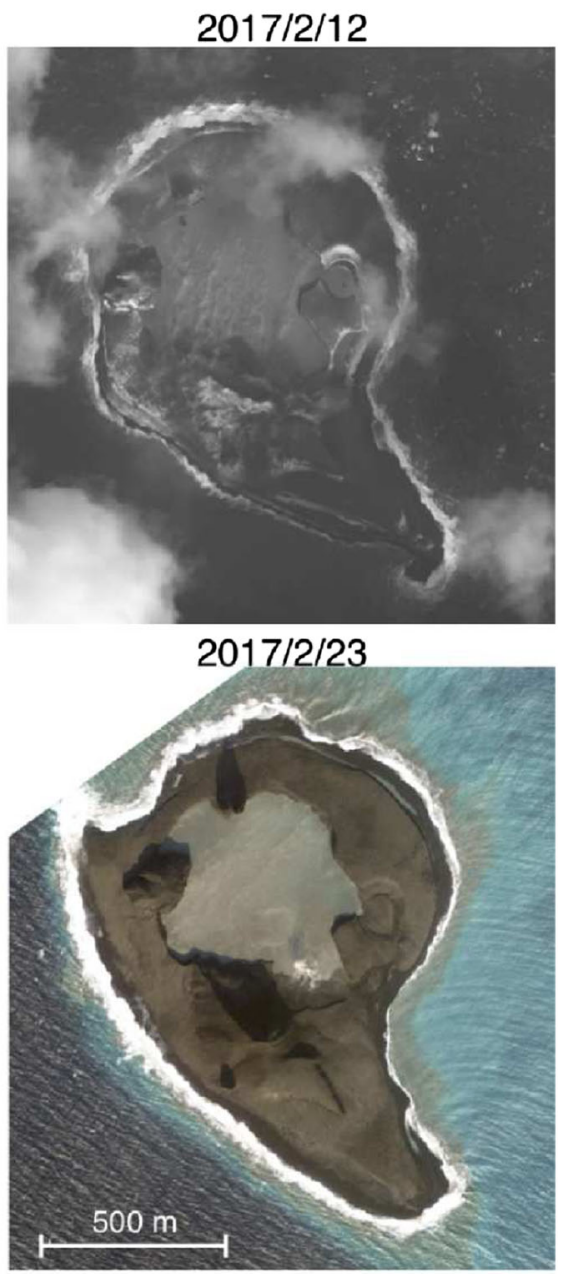

Fig. 6 Seismo-acoustic observations for the February 20, 2017 eruption and satellite images before and after. a) The panels are 0.1$10 \mathrm{~Hz}$ filtered infrasound data, infrasound spectrogram, $0.1-10 \mathrm{~Hz}$ filtered seismic data, seismic spectrogram, infrasound FI, and VASR*.

b) WorldView satellite images before and after the eruption suggest the vent was submerged in the center of the crater. This was typical of eruptions during the sequence

high-amplitude, impulsive bursts occur until the end of the eruption at $\sim 02: 50$. Infrasound frequencies are similar throughout the eruption, and are focused below $1 \mathrm{~Hz}$. FI values range between -2 and -4 . The explosions have high infrasound amplitudes, up to $19 \mathrm{~Pa}$. Numerous earthquakes occur prior to the eruption onset at 02:11. The seismic amplitude then decreases and the earthquakes transition into seismic eruption tremor coincident with the infrasound detection. VASR* is high for the first eruption pulse, peaking at around $0.0012 \mathrm{~Pa} / \mu \mathrm{m} / \mathrm{s}$, then decreases over time. VASR* then varies irregularly during the eruption from $0.00068-0.0078 \mathrm{~Pa} / \mu \mathrm{m} / \mathrm{s}$, and is higher than the January 31 eruption, mostly because of the very high acoustic amplitudes. The eruption also produced an ashpoor plume to $6.1 \mathrm{~km}, 0.7 \mathrm{kt}$ of $\mathrm{SO}_{2}$, and 21 lightning strokes (Lopez et al. 2019; Schneider et al. 2019; Van Eaton et al. 2019). WorldView-2 satellite imagery from this period (Fig. 6b) confirms the vent was submerged in a small lagoon before and after the eruption (Waythomas et al. 2019).

The March 8, 2017 eruption (event 37) contains periods of high infrasound FI and VASR*, similar to January 31; yet, these parameters have a more complex evolution. Figure 7 a shows the infrasound and seismic signals for this event begin rapidly around 07:40 with a relatively high FI around -1 . Infrasound remains elevated until $\sim 10: 20$ UTC, with FI decreasing to -2 to -4 during the middle of eruption and then increasing again to near 0 around 09:45 UTC and then falling once again. Seismicity is quiet prior to the eruption, then increases in amplitude gradually during the middle of the eruption when the infrasound FI is low. VASR* is slightly elevated at the beginning of the eruption, then very low during the middle, then increases substantially 
a)

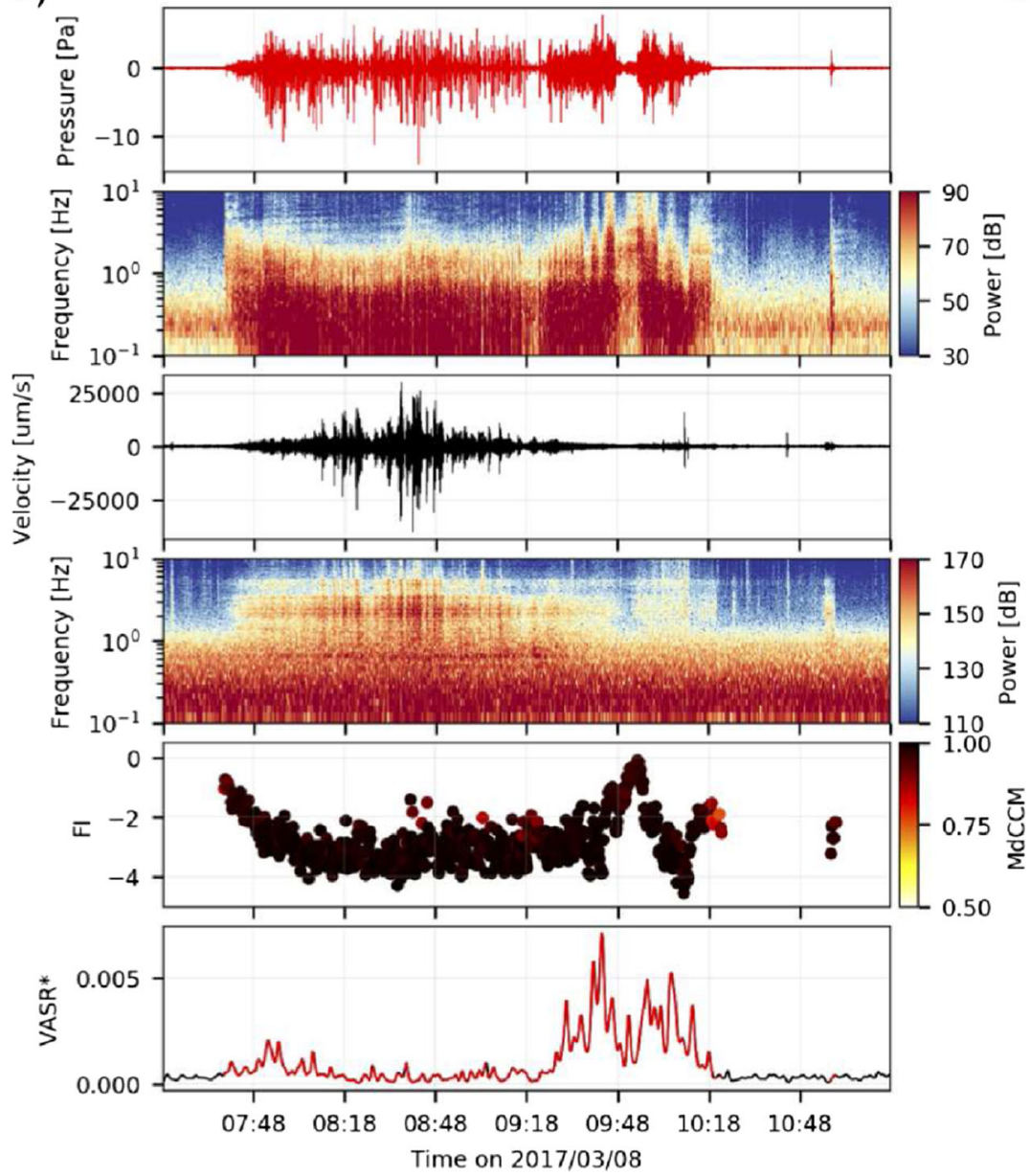

b)

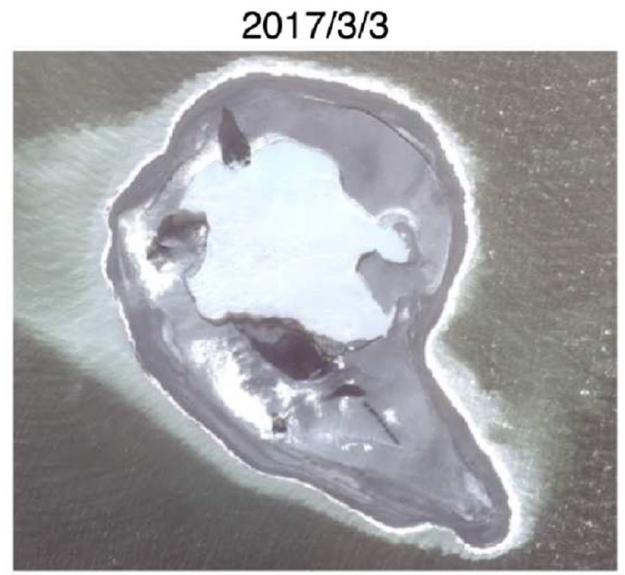

$2017 / 3 / 11$

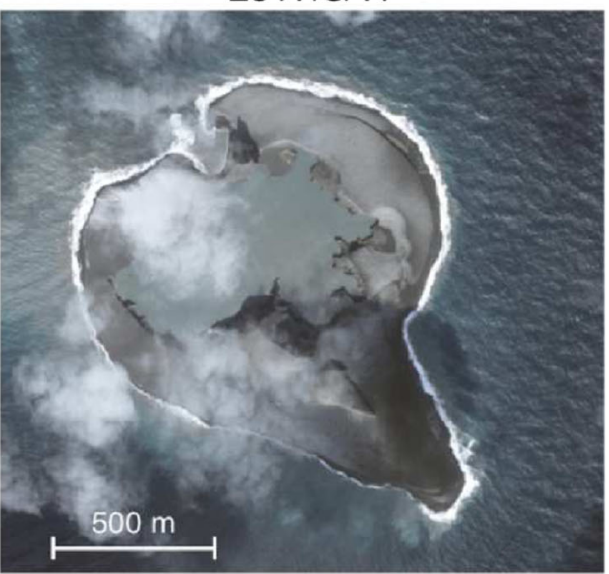

Fig. 7 Seismo-acoustic data and metrics for the March 8, 2017 eruption and before and after satellite images. The panels are $0.1-10$ $\mathrm{Hz}$ filtered infrasound data, infrasound spectrogram, 0.1-10 Hz

toward the end of the eruption. Higher frequency harmonics are apparent in the infrasound spectrogram during periods of high FI.

Satellite images before and after the March 8 eruption similarly suggest a complex eruption progression (Fig. 7b). A Worldview image from March 3 shows a broad, roughly circular lake in the center of the edifice. The next clear image on March 11 shows that during the March 8 eruption the crater lake grew substantially, tephra was deposited along the western shore, and a small new vent opened on the northwest shore of the island. This event also had a relatively substantial, ash-rich plume between 10.6- and $10.8 \mathrm{~km}$ height, with trace to minor ashfall occurring on Unalaska (including Dutch Harbor) and a mariner just offshore the northwest shore of Unalaska island. Extensive lightning and the highest $\mathrm{SO}_{2}(21.5 \mathrm{kt})$ of the eruption were also detected (Table 1). This was likely the most intense eruption of the entire eruption sequence. filtered seismic data, seismic spectrogram, infrasound FI, and VASR*. b) WorldView-2 images between March 3 and 11. The crater lake grew substantially during the March 8 eruption

Eruptions between June 6 and10 (events 44-48) are unique in the 2016-2017 eruption sequence in that an above-water lava dome was visible in satellite imagery beginning late on 5 June (Fig. 8c) (Coombs et al. 2019; Waythomas et al. 2019); thus, eruptions during this period are presumed to be lava dome related and have significant subaerial components. The dome appears to have been destroyed by the June 10 eruption (Fig. 8c). Figure $8 \mathrm{a}$ and b shows the seismo-acoustic data for the June 7 and June 10 eruptions. Similar to other events during these few days, these eruptions have high FI (up to and slightly above 0 with a low around -2 ) (Fig. 2). The June 10 eruption differs somewhat from the other June 6-10 eruptions. The last hour has a gradual decrease in FI to below -3 , potentially corresponding to a change from subaerial to submarine after destruction of the dome earlier in the eruption. Durations of the events on June 6-9 are short $(<200 \mathrm{~s})$ in contrast to June 10 which is much longer (5040 s). VASR * values on June 10 
a)

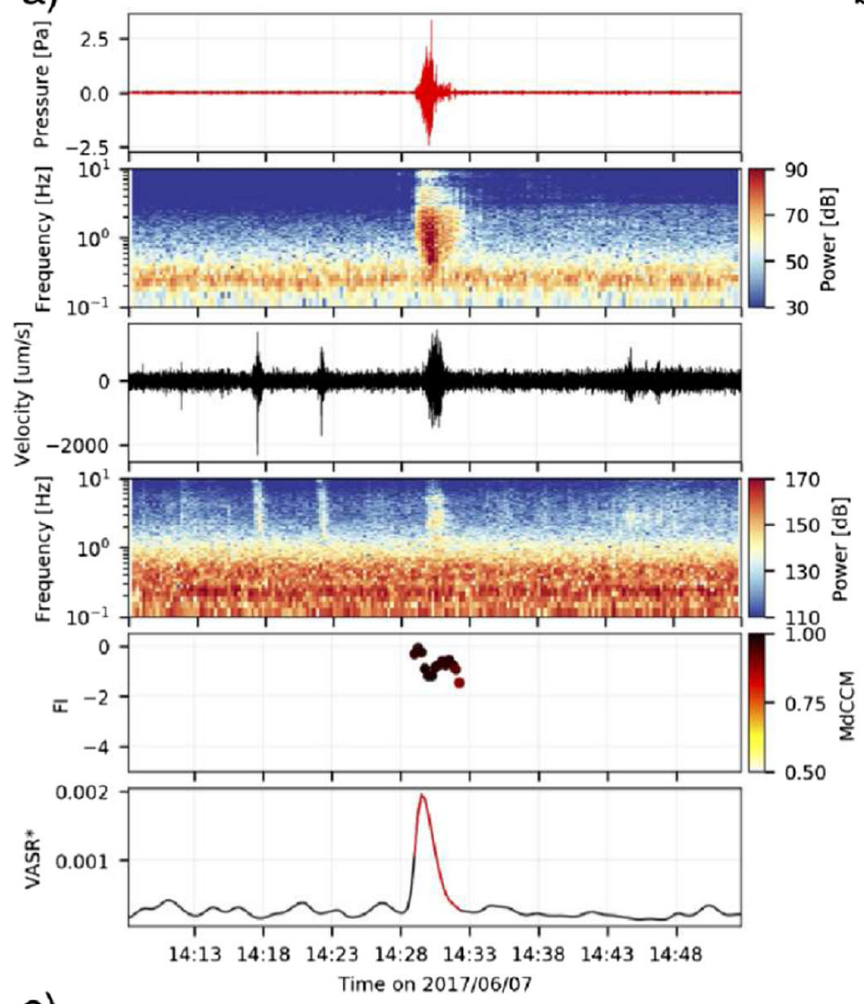

b)

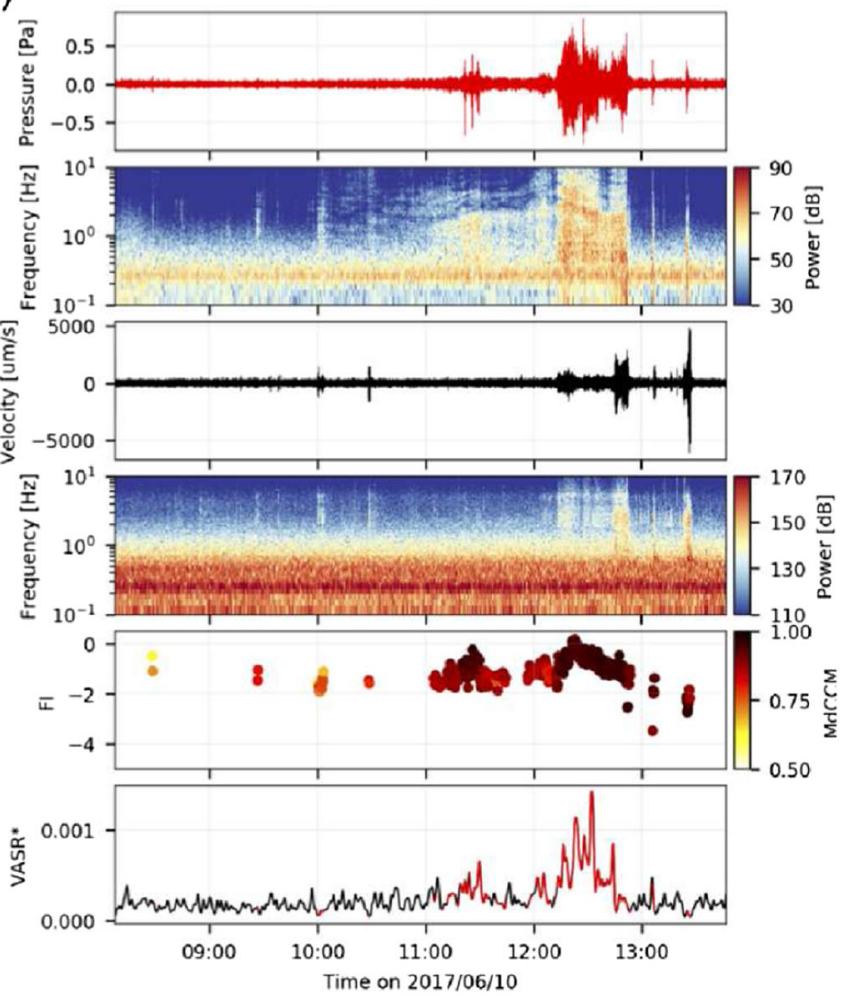

c)
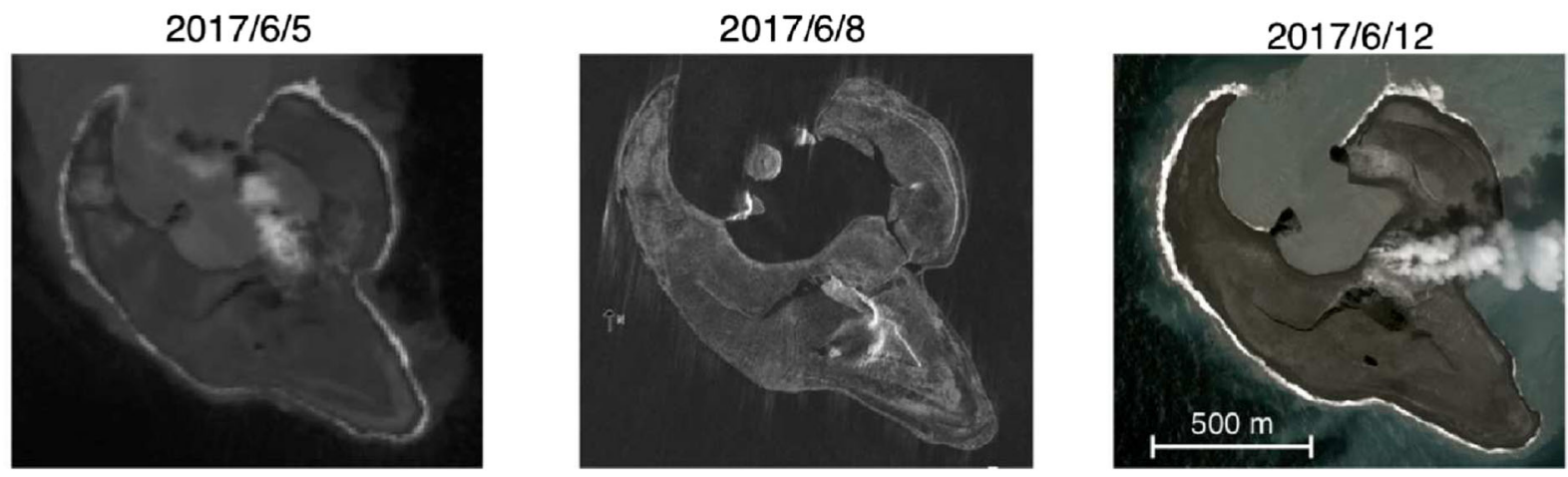

Fig. 8 Seismo-acoustic data and metrics for the June 8 and June 10, 2017 eruptions eruption and before and after satellite images. a) June 8 and b) June $10,0.1-10 \mathrm{~Hz}$ filtered infrasound data, infrasound spectrogram, 0.1-10 Hz filtered seismic data, seismic spectrogram,

show a gradual increase and generally follow the acoustic amplitudes, peaking when the FI peaks. VASR* values peak between 0.0006 and $0.0007 \mathrm{~Pa} / \mu \mathrm{m} / \mathrm{s}$. Plume height was low for the June 6-9 events (not detected or $<3.2 \mathrm{~km}$ ) and quite a bit higher $(9.5 \mathrm{~km})$ on June 10 . Similarly, no lightning or $\mathrm{SO}_{2}$ were detected from the June 6-9 events but numerous strokes and $\mathrm{SO}_{2}$ were detected on June 10 (Table 1).

The August 7, 2017 eruption (event 63) has a progression from low to high FI and VASR*, with peak FI values around -0.5 (Fig. 9a). Maximum infrasound amplitudes are $\sim 1.5 \mathrm{~Pa}$ and VASR $*$ of $\sim 0.0002 \mathrm{~Pa} / \mathrm{m} / \mathrm{s}$ and the duration is infrasound FI, and VASR*. c) Landsat 8, WorldView-2, and COSMO-SkyMed images from June 5, 8, and 12, respectively. The lava dome in the middle of the bay on June 8 was not apparent on June 5 or 12

relatively long at $1860 \mathrm{~s}$. Prior to this eruption, the volcano experienced a lull in activity (last eruption July 11) and the bay in the center of the island was open to the ocean (Fig. 9b). Similar to the January 31 eruption, a Worldview2 image after the August 7 eruption (Fig. 9b) shows the now enclosed crater lake has been enlarged and water is draining back into the below sea level lake. Plume height is estimated $10.8 \mathrm{~km}$, with 4 lightning strokes and a relatively high $5.8 \mathrm{kt}$ of $\mathrm{SO}_{2}$. Clear harmonics are also apparent in the infrasound for the June 7, June 10, and August 7 eruptions. 
a)

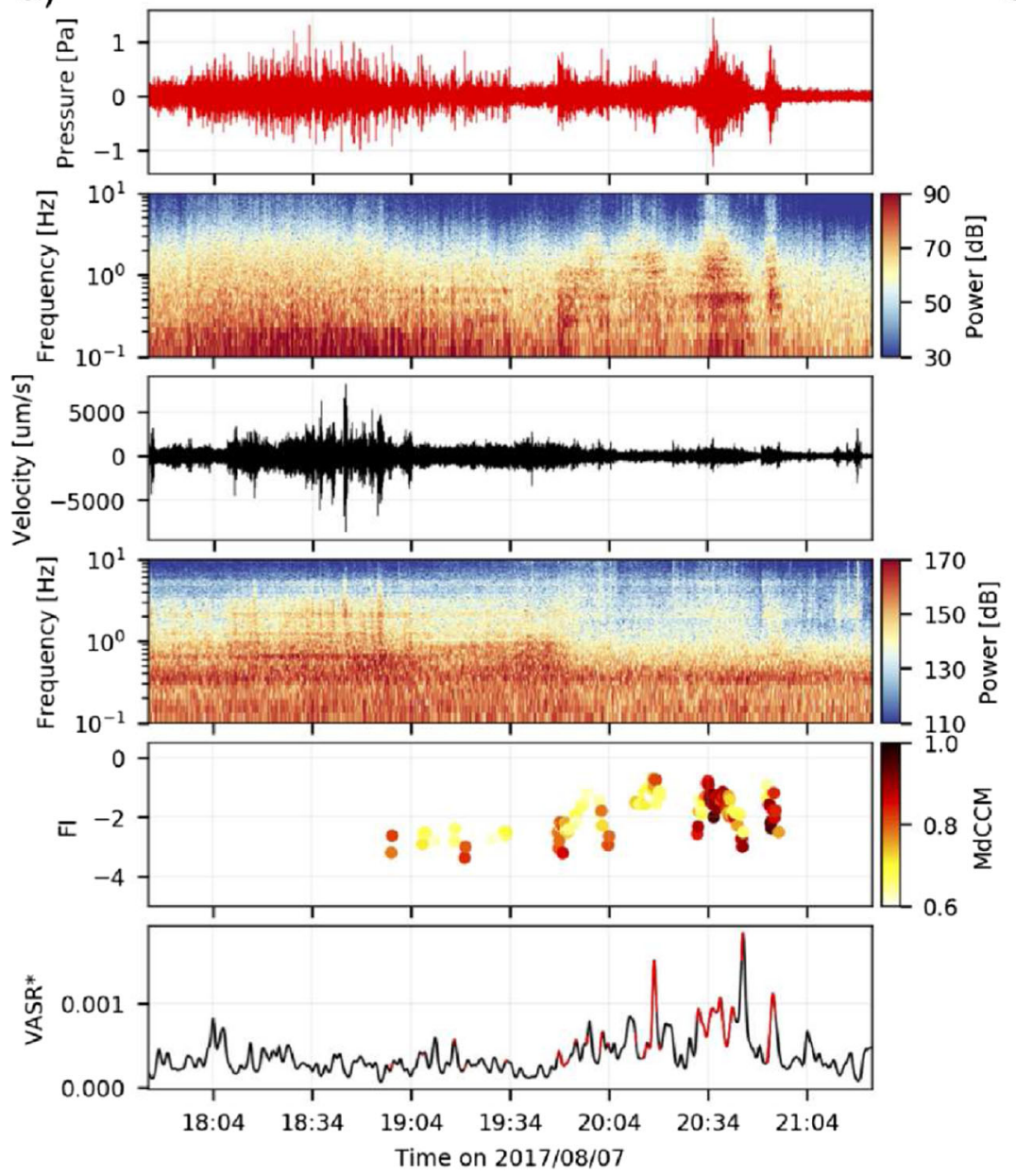

b)

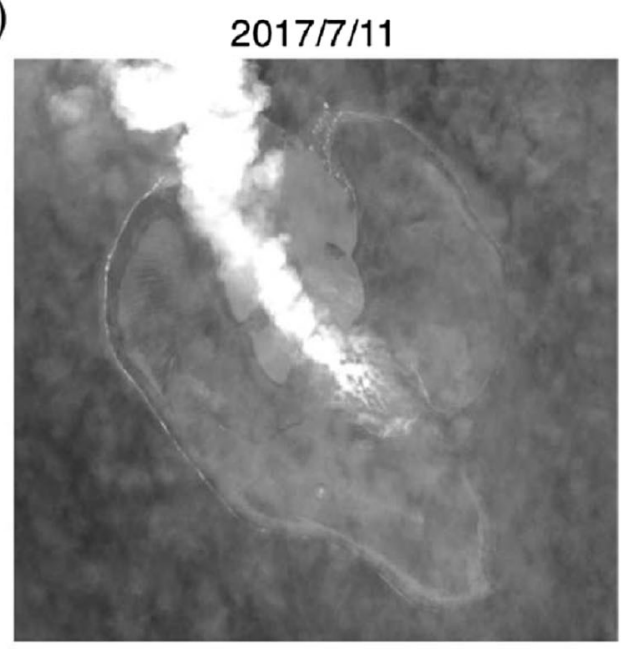

$2017 / 8 / 8$

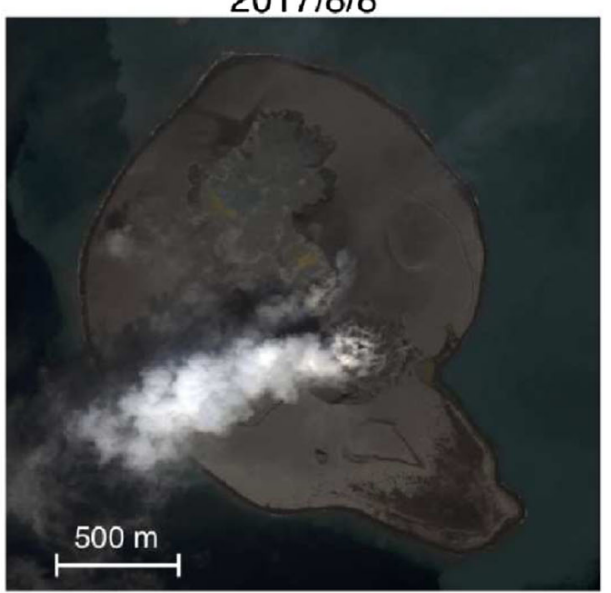

Fig. 9 Seismo-acoustic data and metrics for the August 7, 2017 eruption and before and after satellite images. a) The panels are $0.1-10 \mathrm{~Hz}$ filtered infrasound data, infrasound spectrogram, 0.1-10 Hz filtered seismic data, seismic spectrogram, infrasound FI, and VASR*.

\section{Discussion}

Marked changes in the infrasound frequency content, infrasound duration, and seismic-acoustic amplitude ratio correlate with changes in the surface morphology and the amount of seawater in Bogoslof's vent. High infrasound FI and long event duration corresponds with eruptive events on December 12, 2016, January 31, 2017, March 8, 2017, and August 7, 2017 (Table 1) that are suspected to have had more limited interaction with water and may have temporarily had dry vents. The likely explanation for the high frequency content during these "dry" eruptions is that water was not available to attenuate the higher frequencies of the sound waves. The January 31 event has a long duration and transitions from low to high FI (Fig. 5a), which is presumed to be gradual drying of the vent associated with the progressive displacement or consumption of water in an b) Worldview-2 images from July 11 to August 8, 2017. The crater lake was enlarged during the August 8 eruption and water is visible draining back into the crater after the eruption

intra-island lake as eruptive activity shifted from submarine to subaerial. A tephra ring likely built up around the vent during the first few hours of the eruption (as viewed later in high-resolution satellite data), aiding in blocking seawater from accessing the vent and allowing the eruption to flash available water to steam, displace it from the vent, or both. The March 8 (Fig. 7a), June 10 (Fig. 8a,b), and August 7, 2017 (Fig. 9a) events also have periods of high and low FI, which may represent transitions from a dry-wet or wet-dry vent or some combination. A subaerial lava dome grew in an open submarine embayment on the northern part of the island on June 5-10 and was explosively destroyed on June 10; two events during this period, particularly June 10, also correspond with high FI and a long duration (Fig. 8).

The appearance of a new, small vent on the northwest part of the island on March 8, 2017 (Fig. 7b) also adds complexity to understanding the relationship between 
seismo-acoustic signals and eruptive activity at shallow water vents because during this event it was possible that two and possibly three vents were erupting simultaneously (Waythomas et al. 2019). The December 12, 2016 eruptive event was probably the initial vent opening phase of the 2016-2017 eruption and was likely associated with a subaerial vent. Although few details are available on the exact location of the vent, satellite data from December 14 suggest the vent developed on land (Fig. 4b). Other 2016-2017 Bogoslof eruptive events have generally low infrasound FI and event durations (Fig. 2), suggesting that the vent was predominantly submerged during these events.

The seismic-acoustic ratio also provides insight into the coupling of seismic and acoustic energy into the ground and atmosphere. Multiple events (e.g., Figs. 5 and 7) show a gradual increase in $\mathrm{VASR}^{*}$ and $\mathrm{FI}$, indicating increasing acoustic-seismic efficiency. This may be due to a gradual shift from submarine to subaerial vent conditions as tephra builds up within (and around) the vent, eventually transitioning from a submarine to subaerial eruption. However, this metric is not as conclusive as infrasound FI or duration (at least for this eruption sequence), and is most applicable on the scale of a single event. To this effect, we note that roughly half of the numbered events also produced significant seismicity but no infrasound at OKIF. This could be due to either unfavorable acoustic propagation (Schwaiger et al. 2019) or a low-acoustic efficiency. Therefore, many events may have had a very low VASR $*$, but we are unable to detect the acoustic portion. Examining these parameters for other eruptions would also help determine their utility.

Based on our analyses, it appears that infrasound FI values of approximately -1 correspond to periods of time when the vent was subaerial or mostly dry, suggesting limited magma-water interaction. Therefore, the FI parameter, in conjunction with the event duration, could potentially be used for eruption monitoring to differentiate shallow submarine from subaerial processes. The dotted black line in Fig. 2 connects the maximum FI for each event through time, and we suggest that could be used as a qualitative proxy for vent depth relative to sea level for this eruption sequence. The harmonics in the infrasound spectrogram during periods of high FI (e.g., Figs. 5 and 7) may also correspond to crater resonance (Fee and Matoza 2013, Johnson et al. 2018) indicating an efficient, energetic subaerial eruption. We also note that the infrasound frequency content and FI may change during purely subaerial eruptions. For example, Fee et al. (2010) document the shift to lower frequencies during the subplinian-plinian transition of the August 2006 eruption of Tungurahua volcano, Ecuador. Knowledge on the pre-eruptive state of the vent and availability of water should help inform co-eruptive vent inferences. We acknowledge that numerous other factors, such as multiple vents and variable acoustic propagation conditions, could also affect the seismo-acoustic data. Future analysis of individual eruptive events in context with other observations may help shed light on these processes. Additionally, application of these parameters to other eruptions would help determine their effectiveness.

FI ranges for each event also strongly correlate with infrasound event durations (Fig. 3), suggesting that the longer events, which also tend to be subaerial, produce a broader range of frequencies. This is somewhat expected due to larger amounts of data for long duration events inherently having greater random variability, but the high correlation seems statistically significant. When inferring vent conditions, we suggest the range of FI values should also be considered with peak FI, as subaerial eruptions at Bogoslof can contain both high and low FI values, particularly for events that "dry-out."

Finally, we note that plume height, and therefore assumed mass eruption rate and intensity, does not have a clear relationship with seismic or acoustic amplitude or frequency content (Table 1). For example, the plume heights for both the February 20 and January 31 eruptions were both near $6 \mathrm{~km}$; yet, their infrasound amplitudes, FI, duration, and VASR * were very different. This is apparent for other events of the 2016-2017 Bogoslof eruption sequence as well. Although some other volcanic eruptions appear to have clear scaling relationships between plume height and seismic and/or acoustic amplitude (e.g., McNutt (1994), Ripepe et al. (2013), and Senyukov (2013)), others have a complex and often time-dependent scaling relationship (e.g., Johnson et al. (2005), Matoza et al. (2014), and Fee et al. (2017)). The poor scaling of plume height and seismic or acoustic amplitude at Bogoslof is probably related to the complex, time-dependent coupling of elastic energy into the ground, water, and atmosphere that characterized the 2016-2017 eruptive sequence (Schneider et al. 2019). The eruptive events of assumed dry vent/subaerial eruptions on January 31, March 8, August 7, and to a lesser extent June 6-10, also produced the most ash- and $\mathrm{SO}_{2}$-rich volcanic clouds of the eruptive sequence, possibly because there was less water in the plumes to scrub ash and $\mathrm{SO}_{2}$ out of the atmosphere. This observation highlights the value of developing reliable geophysical indicators of water involvement to understand processes of ash transport relevant to aviation and downwind communities.

\section{Conclusions}

This study investigates a novel way to characterize water involvement during the 2016-2017 shallow submarine eruption of Bogoslof volcano, Alaska. We focus on the infrasound generated during injection of volcanic plumes 
into the atmosphere. In particular, the infrasound frequency content, duration, and seismo-acoustic amplitude ratio are calculated for selected eruptive events and compared to satellite images before and after the eruptions. Our results demonstrate that infrasound, in context with seismic and satellite observations, can provide a robust indicator of seawater involvement in the Bogoslof eruptions. This important information may not be inferable from other datasets, particularly in near-real-time. Using trends in simple metrics, such as the infrasound frequency index (FI), event duration, and acoustic-seismic amplitude ratio, we infer changes in the elastic energy coupling and amount of water in the volcanic vent that are consistent with satellite observations of vent geometry and morphology. High FI values (e.g., >-1) appear to correlate with subaerial vents. Gradual increases in infrasound frequency content during an eruption appear to correspond with transitions, in a relative sense, from submarine to subaerial vent conditions and a diminished or absent role of water resulting in a "drying out" of the vent region. We suggest that infrasound FI provides a means to indirectly infer magmawater interaction that could lead to enhanced scrubbing of volcanic ash and gas from the airborne plumes. Event durations correlate well with the range of FI values and peak FI and suggest long duration events often dried out the vent region due to tephra buildup blocking seawater access to the vent. A trend from low to high VASR* for long duration events also suggests an increase in acoustic efficiency as the vent dried out. These findings are valuable for understanding eruptive processes and hazards because the extent of water involvement strongly affects the atmospheric transport of ash and $\mathrm{SO}_{2}$ (Schneider et al. 2019; Lopez et al. 2019), and production of volcanic lightning (Van Eaton et al. 2019). Our results are also consistent with recent studies that illustrate care should be taken when extrapolating plume height or mass eruption rate from seismic and acoustic frequency content, duration, and amplitude. Lastly, this study highlights the importance of multidisciplinary volcanic studies, particularly for complex activity such as Bogoslof.

Acknowledgments The authors thank David Green, an anonymous reviewer, the Associate Editor, and Michelle Coombs for helpful comments and suggestions. Observations of volcanic activity were made by AVO and are detailed on its website (www.avo.alaska.edu). Kim Angeli and Rick Wessels helped with satellite observations during the eruption sequence. Seismic and infrasound data used here are available from the Incorporated Research Institutions for Seismology Data Center (www.iris.edu). Lightning observations were derived from the World Wide Lightning Location Network (http://wwlln.net) and Vaisala's GLD360. The authors acknowledge support from AVO through the U.S. Geological Survey Volcano Hazards Program and NSF grant EAR-1331084. Any use of trade, firm, or product names is for descriptive purposes only and does not imply endorsement by the U.S. Government.
Open Access This article is distributed under the terms of the Creative Commons Attribution 4.0 International License (http:// creativecommons.org/licenses/by/4.0/), which permits unrestricted use, distribution, and reproduction in any medium, provided you give appropriate credit to the original author(s) and the source, provide a link to the Creative Commons license, and indicate if changes were made.

\section{References}

Belousov A, Belousova M (2009) Eruptive process, effects and deposits of the 1996 and the ancient basaltic phreatomagmatic eruptions in Karymskoye lake, Kamchatka, Russia, in Volcaniclastic Sedimentation in Lacustrine Settings, pp. 35-60, John Wiley \& Sons. https://doi.org/10.1002/9781444304251.ch3

Buurman H, West ME (2006) Seismic precursors to volcanic explosions during the 2006 eruption of Augustine Volcano. In: Power J, Coombs M, Freymueller J (eds) The 2006 eruption of augustine volcano, Alaska, pp 41-57

Coombs ML, Wech AG, Haney MM, Lyons JJ, Schneider DJ, Schwaiger HF, Wallace KL, Fee D, Freymueller JT, Schaefer JR, Tepp G (2018) Short-term forecasting and detection of explosions during the 2016-2017 eruption of Bogoslof volcano. Frontiers in Earth Science, Alaska. https://doi.org/10.3389/feart. 2018.00122

Coombs ML, Wallace K, Cameron C, Lyons JJ, Wech A, Angeli K, Cervelli PF (2019) Overview, chronology, and impacts of the 2016-2017 eruption of Bogoslof volcano, Alaska. Bull Volcanol 81:62. https://doi.org/10.1007/s00445-019-1322-9

Evers LG, Brown D, Heaney KD, Assink JD, Smets PS, Snellen M (2014) Evanescent wave coupling in a geophysical system: airborne acoustic signals from the Mw 8.1 Macquarie Ridge earthquake. Geophys Res Lett 41(5):1644-1650. https://doi.org/10.1002/2013GL058801

Fee D, Matoza R (2013) An overview of volcano infrasound: from Hawaiian to Plinian, local to global, Journal of Volcanology and Geothermal Research, 249. https://doi.org/10.1016/j.jvolgeores. 2012.09.002

Fee D, Garces M, Steffke A (2010) Infrasound from Tungurahua Volcano 2006-2008: Strombolian to Plinian eruptive activity, Journal of Volcanology and Geothermal Research. https://doi.org/10.1016/ j.jvolgeores.2010.03.006

Fee D, Haney M, Matoza R, Van Eaton AR, Cervelli P, Schneider D, Iezzi A (2017) Volcanic tremor and plume height hysteresis from Pavlof Volcano, Alaska, Science, 355(6320). https://doi.org/10. 1126/science.aah6108

Godin OA (2006) Anomalous transparency of water-air interface for low-frequency sound. Physical Review Letters, 97(16)

Green D, Evers L, Fee D, Matoza R, Snellen M, Smets P, Simons D (2013) Hydroacoustic, infrasonic and seismic monitoring of the submarine eruptive activity and sub-aerial plume generation at South Sarigan, May 2010, Journal of Volcanology and Geothermal Research, 257. https://doi.org/10.1016/j.jvolgeores.2013.03.006

Haney MM, Van Eaton AR, Lyons JJ, Kramer RL, Fee D, Iezzi AM (2018) Volcanic thunder from explosive eruptions at Bogoslof volcano. Alaska, Geophysical Research Letters. hhtps://doi.org/ 10.1002/2017GL076911

Haney MM, Van Eaton AR, Lyons JJ, Kramer RL, Fee D, Iezzi AM, Dziak RP, Anderson JF, Johnson JB, Lapierre JL, Stock M (2019) Characteristics of thunder and electromagnetic pulses from volcanic lightning at Bogoslof Volcano. Bull Volcanol (part of the Bogoslof Topical Collection), Alaska

Iezzi AM, Schwaiger HF, Fee D, Haney MM (2018) Application of an updated atmospheric model to explore volcano infrasound 
propagation and detection in Alaska, Journal of Volcanology and Geothermal Research. https://doi.org/10.1016/j.jvolgeores.2018. 03.009

Johnson JB, Aster RC (2005) Relative partitioning of acoustic and seismic energy during Strombolian eruptions. J Volcanol Geotherm Res 148(3-4):334-354. https://doi.org/10.1016/j.jvolgeores.2005. 05.002

Johnson JB, Ruiz MC, Lees JM, Ramon P (2005) Poor scaling between elastic energy release and eruption intensity at Tungurahua Volcano, Ecuador. Geophys Res Lett 32(15):5

Johnson JB, Watson LM, Palma JL, Dunham EM, Anderson JF (2018) Forecasting the eruption of an open-vent volcano using resonant infrasound tones, Geophysical Research Letters, 45. https://doi.org/10.1002/2017GL076506

Jolly AD, Sherburn S, Jousset P, Kilgour G (2010) Eruption source processes derived from seismic and acoustic observations of the 25 September 2007 Ruapehu eruption-North Island, New Zealand, Journal of Volcanology and Geothermal Research. https://doi.org/10.1016/j.jvolgeores.2010.01.009

Kilgour G, Manville V, Pasqua FD, Graettinger A, Hodgson KA, Jolly GE (2010) The 25 September 2007 eruption of Mount Ruapehu, New Zealand: Directed ballistics, surtseyan jets, and ice-slurry lahars. J Volcanol Geotherm Res 191(1-2):1-14. https://doi.org/10.1016/j.jvolgeores.2009.10.015

Kokelaar BP (1983) The mechanism of Surtseyan volcanism. J Geol Soc 140(6):939-944

Lee D-C, Olson JV, Szuberla CAL (2013) Computationally robust and noise resistant numerical detector for the detection of atmospheric infrasound, The Journal of the Acoustical Society of America. https://doi.org/10.1121/1.4807802

Lopez TM, Clarisse L, Schwaiger HF, Van Eaton AR, Loewen M, Fee D, Lyons JJ, Wallace KL, Wech A, Haney MM, Schneider DJ, Graham N (2019) Constraints on eruption processes and event masses for the 2016-2017 eruption of Bogoslof volcano, Alaska, through evaluation of satellite $\mathrm{SO} 2$ masses and complementary datasets. Bull Volcanol (part of the Bogoslof Topical Collection)

Lyons JJ, Haney MM, Fee D, Wech A, Waythomas CF (2019) Infrasound from giant bubbles during explosive submarine eruptions. Nat. Geosci. 12:952-958. https://doi.org/10.1038/s41561019-0461-0

Lyons JJ, Iezzi AM, Fee D, Schwaiger HF, Wech A, Haney MM (2019) Infrasound generated by the 2016-17 shallow submarine eruption of Bogoslof volcano, Alaska. Bull Volcanol (part of the Bogoslof Topical Collection)

Matoza R, Fee D, López T (2014) Acoustic characterization of explosion complexity at Sakurajima, Karymsky, and Tungurahua volcanoes, Seismological Research Letters, 85(6). https://doi.org/10.1785/0220140110

McNutt SR (1994) Volcanic tremor amplitude correlated with the volcano explosivity index and its potential use in determining ash hazards to aviation. Acta Vulcanol 5:193
Morimoto R, Ossaka J (1955) Submarine Eruption of the Myojin Reef near the Bayonnaise Rocks, Japan, Tokyo Univ. Earthquake Research Inst Bull 33(2):221-250

Prosser WT (1911) Nature turned sorceress, The Technical World Magazine, pp 64-68

Ripepe M, Bonadonna C, Folch A, Delle Donne D, Lacanna G, Marchetti E, Höskuldsson A (2013) Ash-plume dynamics and eruption source parameters by infrasound and thermal imagery: the 2010 Eyjafjallajökull eruption. Earth Planet. Sci Lett 366:112121. https://doi.org/10.1016/j.epsl.2013.02.005

Schneider DJ, Van Eaton AR, Wallace KL (2019) Satellite observations of the 2016-17 eruption of Bogoslof volcano: aviation and ash fallout hazard implications from a water-rich eruption. Bull Volcanol (part of the Bogoslof Topical Collection)

Schwaiger HF, Lyons JJ, Iezzi AM, Fee D (2019) Evolving infrasound detections from Bogoslof volcano, Alaska: insights from forward modelling. Bull Volcanol (part of the Bogoslof Topical Collection)

Senyukov SL (2013) Monitoring and prediction of volcanic activity in Kamchatka from seismological data: 2000-2010, Journal of Volcanology and Seismology. https://doi.org/10.1134/S07420463130 10077

Shean DE, Alexandrov O, Moratto ZM, Smith BE, Joughin IR, Porter C, Morin P (2016) An automated open-source pipeline for mass production of digital elevation models (DEMs) from very-high-resolution commercial stereo satellite imagery, ISPRS Journal of Photogrammetry and Remote Sensing. https://doi.org/10.1016/j.isprsjprs.2016.03.012

Symonds RB, Gerlach TM, Reed MH (2001) Magmatic gas scrubbing: implications for volcano monitoring, Journal of Volcanology and Geothermal Research. https://doi.org/10.1016/S0377-0273 (00)00292-4

Szuberla CAL, Olson JV (2004) Uncertainties associated with parameter estimation in atmospheric infrasound arrays. J Acoust Soc Am 115(1):253-258. https://doi.org/10.1121/1.1635407

Van Eaton AR, Mastin LG, Herzog M, Schwaiger HF, Schneider DJ, Wallace KL, Clarke AB (2015) Hail formation triggers rapid ash aggregation in volcanic plumes, Nature Communications. https://doi.org/10.1038/ncomms 8860

Van Eaton AR, Schneider DJ, Smith CM, Haney MM, Lyons JJ, Said R, Fee D, Holzworth RH, Mastin LG (2019) Did ice-charging generate volcanic lightning during the 2016-2017 eruption of Bogos lof volcano, Alaska? Bull Volcanol (part of the Bogoslof Topical Collection)

Waythomas CF, Cameron CE (2018) Historical eruptions and hazards at Bogoslof volcano, Alaska, U.S. Geological Survey Scientific Investigations Report 2018-5085, p 42. https://doi.org/10.3133/ $\operatorname{sir} 20185085$

Waythomas CF, Angeli K, Wessels R, Schneider DJ (2019) 2016-17 evolution of the submarine-subaerial edifice of Bogoslof volcano. Alaska, based on analysis of satellite imagery. Bull Volcanol (part of the Bogoslof Topical Collection) 